\title{
SWATH- A new concept for the Safety and Security at Sea
}

Fritz Grannemann ${ }^{1}$

\begin{abstract}
SWATH means Small Waterplane Area Twin Hull and is guarantor for excellent sea keeping behaviour. The basis of this ship type was born in the 1960's and 70's when semi-submersible vessels were introduced to the offshore market. Naval architects developed these vessels further and it was used as navy test craft, pilot tender, yachts, passenger boats etc.

The German Shipyard Abeking \& Rasmussen has more than 100 year of experience in innovative ships and designs. Since 1999 more than 20 SWATH vessels like pilot tender, pilot station vessel, explorer yacht, wind park maintenance tender, offshore patrol vessels and a hydrographical research vessel were built.

This paper should give an insight to the SWATH technology and the implementation in the market. Different applications and ideas will be shown. Whatever you need - a navy ship, a workboat, a multipurpose platform a ferry or a yacht - there are many possibilities.
\end{abstract}

Key words: Small Waterplane Area Twin Hull, seakeeping, platforms, ship design.

\section{Resumen}

SWATH significa Small Waterplane Area Twin Hull ( Cascos Dobles con Pequeña Área de Flotación ) embarcación que garantiza un excelente comportamiento marinero. El fundamento de este tipo de buque nació en los años 1960 y 70, cuando se introdujeron en el mercado offshore las plataformas semisumergibles. Desde entonces los arquitectos navales de Abeking \& Rasmusen han desarrollado más y nuevos diseños que han sido utilizados como embarcaciones de prueba para la marina armada, transporte de pilotos, yates, barcos de pasajeros, etc.

El astillero alemán Abeking \& Rasmussen tiene más de 100 años de experiencia en construcción de barcos y de llevar a cabo diseños innovadores. A partir de 1999, Abeking \& Rasmussen ha contruído más de 20 embarcaciones tipo SWATH para servicios tales como transporte de pilotos, buque-estación de pilotos, yate explorador, embarcaciones para el mantenimiento de parques eólicos en costa afuera, buques de patrulla en alta mar y un barco de investigación hidrográfica.

Esta presentación dará una visión de la tecnología SWATH y sus aplicaciones en el mercado. Se mostrarán sus diferentes aplicaciones e ideas. Lo que Usted necesite - un buque para la Armada, un barco de trabajo, una plataforma multiusos, un ferry o un yate - contamos con muchas y diversas opciones.

Palabras claves: Cascos Dobles con Pequeña Área de Flotación, comportamiento en el mar, plataformas, diseño de embarcaciones

Date Received: January 7th, 2015 - Fecha de recepción: 7 de enero de 2015

Date Accepted: March 18th, 2015 - Fecha de aceptación: 18 de marzo de 2015

${ }^{1}$ Exclusive Representative of Abeking \& Rasmussen. Mexico. Email: fritz.grannemann@globe.mx 


\section{Introduction}

The seakeeping capability of conventional ships depends mostly on their size and displacement. Naval architects usually optimize seakeeping behavior by well chosen main dimensions and refined hull lines.

Depending on sea state, a vessel is exposed to alternating accelerations, rolling and pitching motions. The difficulty is not to design a vessel strong enough to withstand those environmental forces, but exposing sailors operating the vessel to these adverse conditions over a longer period of time.

Various stabilization systems have been developed to reduce rolling and pitching, some with remarkable results, but all of these systems have their limits as they cannot push beyond the limit set by physics.

By mastering a unique design, which focuses on minimizing the waterplane area of the vessel, A\&R succeeded in reducing roll, pitch and accelerations in bad weather conditions to a comfortable level, even for non-sailors.

Since 1999 SWATH@A\&R -vessels are in daily service in the German Bight providing pilots a safe and stable platform with exceptional seakeeping capabilities. Over the years other applications were explored, designed and built and by today more than 20 SWATH vessels have been delivered.

This paper presents an overview of semi-submersible technology at the state-of-the-art for twin hull vessels and the special features developed by $A \& R$.

\section{What makes a SWATH a SWATH?}

The buoyancy of a SWATH is provided by fully submerged, torpedo-like bodies, which are connected by single or twin struts to the upper platform. The cross-section at waterline level is minimized and thus lowering the hydrostatic restoration forces at design draft. The resulting wave induced motions in the vertical plane are reduced about one quarter of those of comparable monohulls. Fig. 1 shows a comparison of waterline areas for different hull configurations. The buoyancy of a SWATH is provided by fully submerged, torpedo-like bodies, which are connected by single or twin struts to the upper platform. The cross-section at waterline level is minimized and thus lowering the hydrostatic restoration forces at design draft. The resulting wave induced motions in the vertical plane are reduced about one quarter of those of comparable monohulls. Fig. 1 shows

Fig. 1. Comparison of different waterline areas.
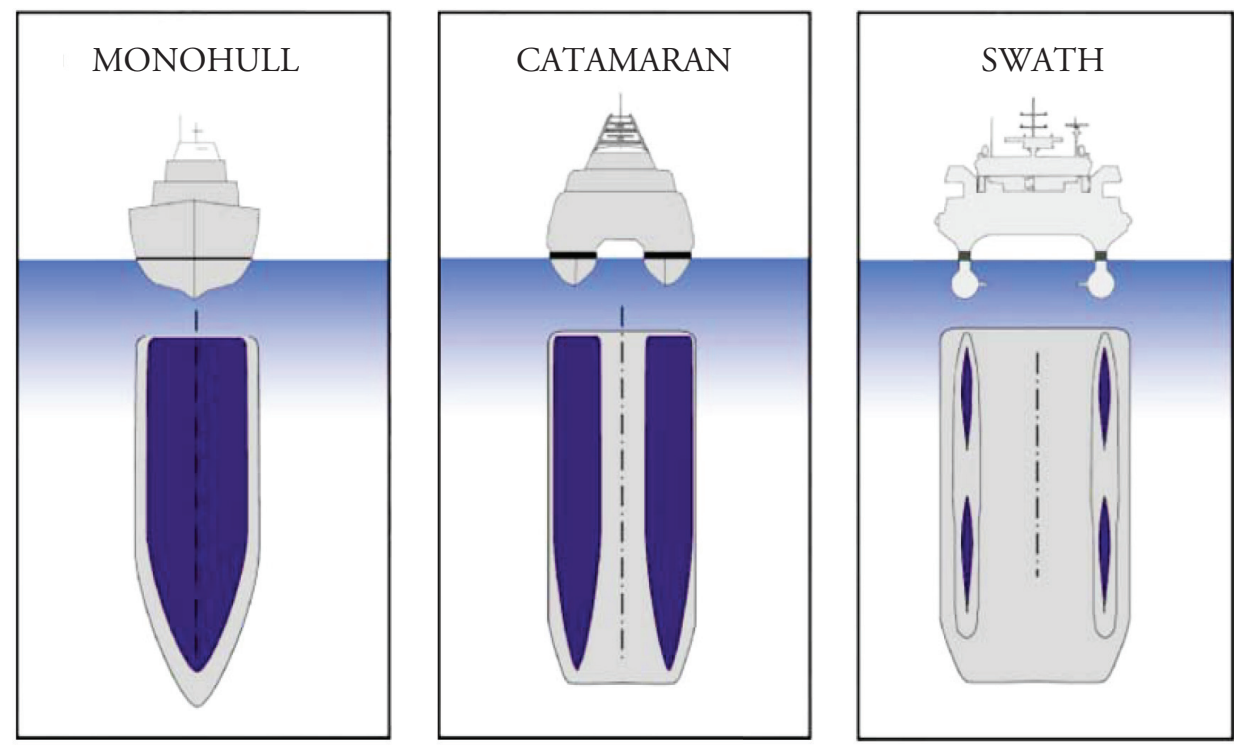
a comparison of waterline areas for different hull configurations.

Using the precise wording of the German War Weapon Control Law, a SWATH is a craft with reduced waterplane area $\left(A_{W L}\right)$ relative to its displaced volume $(\nabla)$, specifically:

$$
A_{W L}<2 \cdot \nabla^{2 / 3}
$$

Two design justifications for reducing the waterplane area are:

- to reduce the wave-making resistance

- to reduce sea-induced ship motions

The original intention for the design of SWATH vessels was probably to develop unconventional fast crafts by reduction of wave-making resistance. $A \& R$ concentrated on the reduction of sea-induced ship motions to improve seaworthiness, crew effectiveness and vessel availability in bad weather conditions.

A SWATH@A\& $\mathrm{R}^{\circledR}$ is by definition a fast displacement vessel. It is designed for operation at speeds up to a Froude number of 0.75 , without slamming. These are speeds higher than those of frigates, refrigerated carrierers or corvettes, when related to ship length.

Semi-submersibles can be classified by the number of displacement bodies in each configuration. Table 2 divides SWATH configurations into design configurations.
The evolution of SWATH design from first generation to third increases the complexity of the development process because of the increasingly complicated interactions of the displaced bodies. The analysis of hydrodynamic and structural factors, including the optimization of resistance, becomes more difficult, increasing the required qualifications for naval architects during design development.

The greater the number of displacement bodies in a SWATH design, the greater the potential for meeting specific design requirements. At the same time, increased complexity of the design procedure adds to the sensitivity of the design to construction inaccuracies, expressed as excess weight or inadequate hull structure.

\section{Generation I SWATH: single strut}

\section{Advantages:}

- good accessibility to spaces in lower hulls

- good transverse strength

- simple construction

- $\quad$ significantly reduced ship motions compared to monohulls and catamarans

Disadvantages:

- dissimilar transverse and longitudinal stability

- hydrodynamic efficiency (resistance and seakeeping) limited by layout

- sensitive to speed dependent trim moments (Munk moments)

Table 1.SWATH generations.

\begin{tabular}{|c|c|c|c|}
\hline \multirow{2}{*}{$\begin{array}{c}\text { Type } \\
\text { Monohull }\end{array}$} & \multicolumn{2}{|c|}{$\begin{array}{c}\text { Configuration modularity } \\
\text { Mission modularity }\end{array}$} & \multirow{2}{*}{$\begin{array}{l}\text { Status } \\
\text { proven }\end{array}$} \\
\hline & 1 Hull & 1 & \\
\hline Catamaran & 2 Hulls & 2 & proven \\
\hline $\begin{array}{c}\text { Generation I SWATH } \\
\text { (single strut) }\end{array}$ & $\begin{array}{l}2 \text { Struts } \\
2 \text { Torpedos }\end{array}$ & 4 & proven \\
\hline $\begin{array}{l}\text { Generation II SWATH } \\
\text { (twin strut) }\end{array}$ & $\begin{array}{l}4 \text { Struts } \\
2 \text { Torpedos }\end{array}$ & 6 & proven \\
\hline $\begin{array}{c}\text { Generation III SWATH } \\
\text { (SLICE) }\end{array}$ & $\begin{array}{l}4 \text { Struts } \\
4 \text { Torpedos }\end{array}$ & 8 & experimental \\
\hline $\begin{array}{c}\text { Generation IV SWATH (single strut, } \\
\text { single hull) (SWASH) }\end{array}$ & $\begin{array}{l}1 \text { Strut } \\
1 \text { Torpedo }\end{array}$ & 2 & experimental \\
\hline
\end{tabular}


Fig. 2. Generation I SWATH

$2 \times 2$ buoyancy hulls, usually streamlined, single struts and relative large waterplane area.
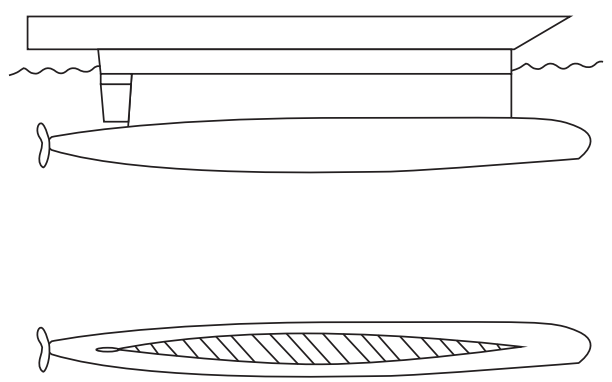

\section{Generation II SWATH: twin strut}

Advantages:

- more options for hull form shape to optimize resistance

- longitudinal stability can be matched to transverse for optimal seakeeping compared to Generation I SWATH (single strut)

- higher speed with stability in smooth water or a seaway

- compared with Generation I SWATH (single strut) further reduction of ship motion

- more sensitive reaction of ride control action, even stability longitudinally is increased

Disadvantages:

- limited accessibility to lower hull spaces („bottle necks“ in the struts for maintenance, ventilation, manholes, emergency exits)

- increased requirements to an optimized hull structure

Fig. 3. Generation II SWATH

$2 \times 3$ buoyancy hulls, with optimized hull form and minimized waterplane area. The different buoyancy parts (twin strut and longer hull) interact depending on form, length and width.
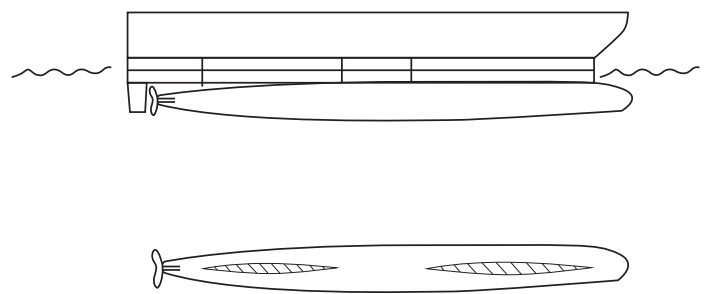

\section{SWATH vs. Monohull}

Human beings which are permanently exposed to sea response motions (i.e. alternating accelerations) suffer from lack of concentration, exhaustion and seasickness. Even if experienced sailors get accustomed to motions of a vessel, it only prolongs the period of time when exhaustion and fatigue occurs.

In order to keep crew and passengers fairly comfortable and enable them to perform their main duties, limits have been defined, e.g. by the U.S. Navy or by ISO for the permanent allowable accelerations on board of seagoing vessels.

Following limits are widely accepted:

- Crew and passenger comfort: 0,2 g

- Operating limit experienced Crew: $0,4 \mathrm{~g}$

Fig. 4 shows a comparison between vertical accelerations onboard a $33 \mathrm{~m}$ A\&R built DeepVee Monohull and a slightly smaller $25 \mathrm{~m}$ SWATH@A\&R $\mathrm{R}^{\odot}$ Pilot Tender. Measurements were conducted at various speeds in head seas of approximately $2 \mathrm{~m}$ and $3 \mathrm{~m}$ significant wave height respectively which corresponds to about sea state 5 .

To stay within the "Crew Limit" of $4 \mathrm{~m} / \mathrm{s}^{2}$, the maximum speed of the DeepVee vessel needs to be reduced to 16 and 20 knots depending on sea state.

In comparison, the $25 \mathrm{~m}$ SWATH@A\& $\mathrm{R}^{\odot}$ Pilot Tender maintains its top speed of 20 knots even without exceeding the "Crew Comfort" limit of $2 \mathrm{~m} / \mathrm{s}^{2}$.

\section{SWATH@AR Design Features}

\section{General Design Concepts}

$\mathrm{A} \& \mathrm{R}$ has until today developed and built four different groups of SWATH vessels defined mainly by length and deadweight capacity. Each group is characterized by the same underwater 
body hull form, strut configuration, platform design and hull structure. Given the constraints for weight and centers of gravities, almost any other change to the designs are practicable which has been successfully proven by $A \& R$ in several cases (Table 2).

\section{Propulsion Concepts}

Both diesel-electric and diesel-mechanic propulsion concepts are available for allSWATH@ $\mathrm{AR}^{\ominus}$ vessels. Depending on the main task of the vessel, the most suitable concept with regards to operational and economical requirements is installed.

The contrast between both propulsion concepts is noticeable, especially for the smaller $25 \mathrm{~m}$ SWATH. Two diesel-generators are installed within the platform above water level providing power for electric motors which are installed within the displacement bodies below water level. Each of the electric motors drive fixed pitch propellers through reduction gearboxes

Fig. 4. Comparison of vertical accelerations.

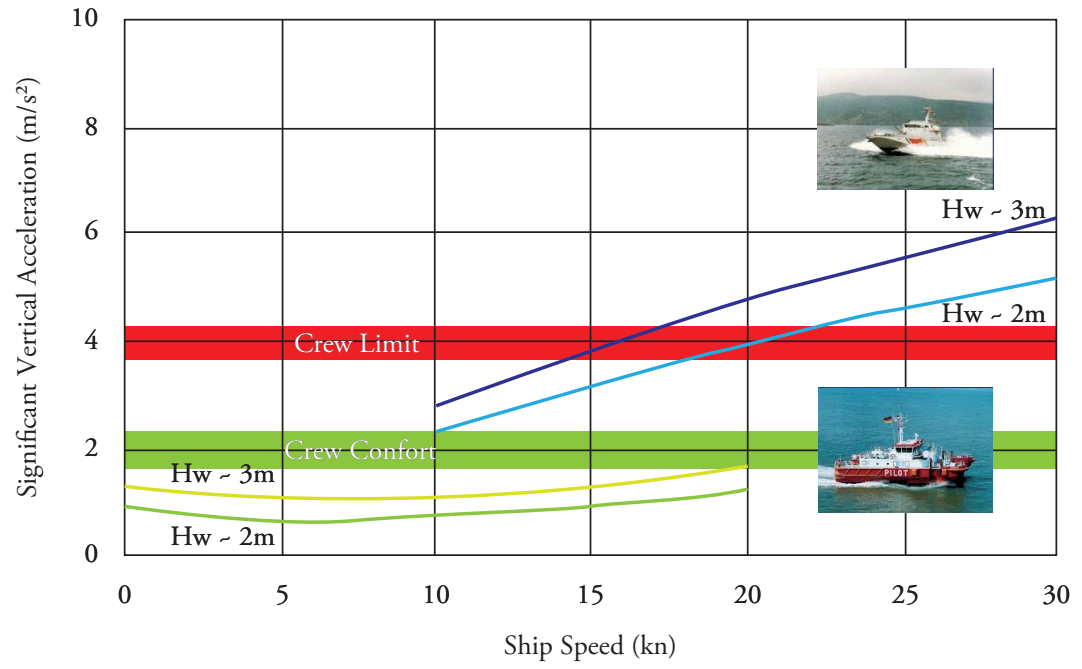

Table 2. Different applications of SWATH@AR®.

\begin{tabular}{|c|c|c|}
\hline Group & $\begin{array}{c}\text { Configuration modularity } \\
\text { Mission modularity }\end{array}$ & Status \\
\hline $25 \mathrm{~m}$ SWATH & $\begin{array}{l}\text { Pilot Tender } \\
\text { Hydrographic Research Vessel } \\
\text { PV - Patrol Vessel } \\
\text { MCMV - Mine Countermeasures Vessel } \\
\text { USV - Unmanned Surface Vehicle } \\
\text { Wind Farm Crew and Maintenance Vessel }\end{array}$ & $\begin{array}{l}\text { built } \\
\text { built } \\
\text { built } \\
\text { experimental } \\
\text { project } \\
\text { built }\end{array}$ \\
\hline $40 \mathrm{~m}$ SWATH & $\begin{array}{l}\text { Explorer Super Yacht } \\
\text { Crew Supply Vessel } \\
\text { Research Vessel }\end{array}$ & $\begin{array}{l}\text { built } \\
\text { project } \\
\text { project }\end{array}$ \\
\hline $50 \mathrm{~m}$ SWATH & $\begin{array}{l}\text { Pilot Station Ship } \\
\text { Wind Farm Maintenance and Hotel Vessel }\end{array}$ & $\begin{array}{c}\text { Built } \\
\text { project }\end{array}$ \\
\hline $60 \mathrm{~m} \mathrm{SWATH}$ & $\begin{array}{l}\text { Pilot Station Ship } \\
\text { Wind Farm Maintenance and Hotel Vessel } \\
\text { SIGINT Vessel (SIGnal INTelligence) } \\
\text { Research Vessel }\end{array}$ & $\begin{array}{l}\text { built } \\
\text { project } \\
\text { project } \\
\text { project }\end{array}$ \\
\hline
\end{tabular}


enabling speeds up to 20 knots. A\&R succeeded in implementing a diesel-mechanic propulsion where propulsion diesels are installed within the displacement bodies below water level driving controllable pitch propellers through reduction gearboxes enabling even higher speeds up to 21.4 knots.

Advantages of the diesel-mechanic propulsion are:

- added space within the platform which can be utilized for extra cabins or other purposes

- low noise and vibration levels since exciters are installed below water level remote from personnel onboard

\section{General Design Concepts}

A multi-purpose tool contains a variety of elements in one basis. The different tasks can be fulfilled by "switching" from one to the other element. By the nature of such a tool, the integration of the different elements requires compromises with regard to handling the tool and the integration of other elements. Some bulked variants of the well known Swiss Army Knife represent best whereto multi-purpose might lead. A modular tool consists of one common basis which can be supplemented by modules for a dedicated task. By exchanging the modules the tool can be configured for various different tasks and at the same time each configuration represents a dedicated tool. A socket wrench set is the best example for such a modular tool. Dedicated, single tasked vessels are hardly affordable in an era of shrinking budgets while the mission variety is increasing, which is the case especially for navies and authorities. With decreasing number of hulls within most fleets, modular or multi-purpose "tools" are considered to be the solution for executing all required naval tasks.

$A \& R$ responded to these requirements by implementing a containerized solution to its $25 \mathrm{~m}$ SWATH. One module with the size of a standard ISO $20 \mathrm{ft}$. container can be stored in front of the superstructure in-between the stems (Figs. 5 and 6).
Fig. 5. 20' container storage for modules.

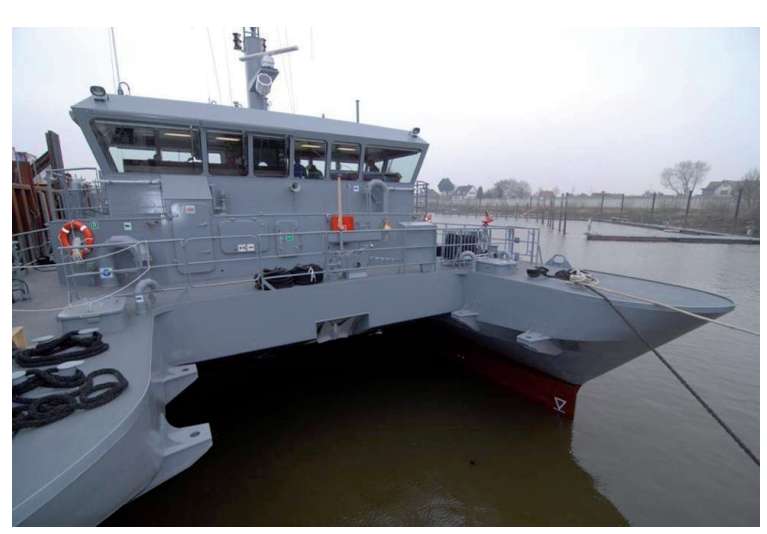

Fig. 6. Example of a gun module.

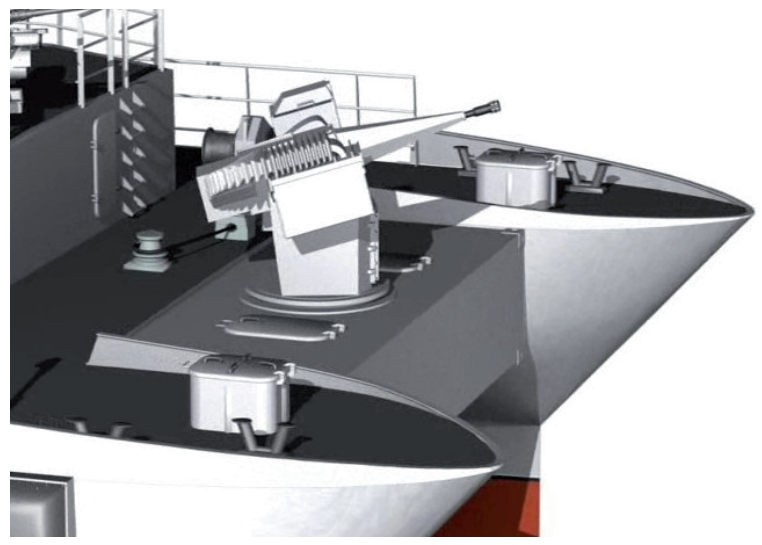

The gun module fitted with a medium calibre gun contains all subsystems necessary for operation of the gun, including ammunition. Only electric voltage $(440 \mathrm{~V})$ will be supplied, target data will be transmitted by a data bus. Due to this limited interface requirement, the gun module can also be used on other units and even onshore.

Under condition of a compatible target assignment format, modules can be used by army units as well, e.g. for camp protection tasks. This brings the advantages of modular ship design into a "joint" account.

Instead of the gun module, other modules are possible for secondary tasks. The interfaces remain the same, i.e. only electric voltage, connection to the ship's data bus plus seawater and possibly freshwater. These interfaces will be available on almost every other craft of opportunity thus broadening the basis of using 
Fig. 7. ROV module, oil spill response module, diving chamber module and gun module.
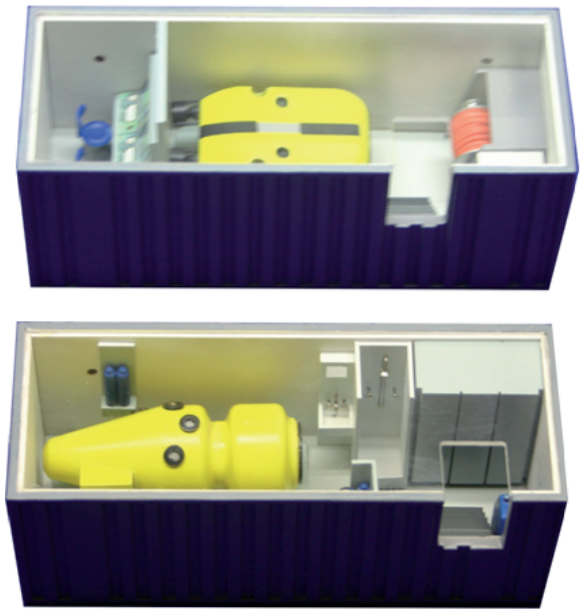

the modules other than installed on board of the 25 m SWATH.

A module equipped with sonar ROV will enable MCM operations, such as e.g. route survey. Even a hyper baric diving chamber and breathing air compressor might be fitted for diving operations. The stable SWATH makes a perfect platform for diving operations. Access to the water is conveniently given by a hydraulic lift on the starboard side which reaches from main deck level well below the water surface.

Other modules might contain equipment for oil pollution control or hydrographic research equipment. Further applications can be developed as long as it is within the geometrical dimensions and the maximum weight. This allows cost effective future upgrades and enhancements of secondary missions.

\section{Redundancy}

Depending on the requirements and operational profile of a vessel, different redundancy levels for propulsion and ship's service system can be achieved with a SWATH. In any case two independent compartments comprising both lower hulls including two identical propulsion systems (one in each hull) are available. Given this compartmentation, gensets, auxiliary systems and electric panels need to be located in separate and independent engine rooms
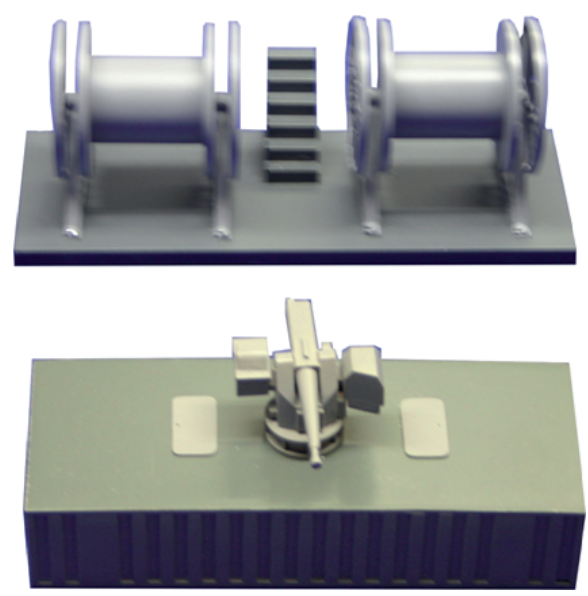

within the superstructure to achieve extra safety and redundancy effects. This can be achieved with small structural changes within the platform and of course with duplication of systems as required by redundancy class. An additional benefit is the large spatial distance between both propulsion trains providing additional safety.

\section{SWATH@A\&R® in Service}

\section{5 m SWATH@A\&R® Pilot Tender Mk I}

Fig. 8. A\&R Pilot Tenders MK I.

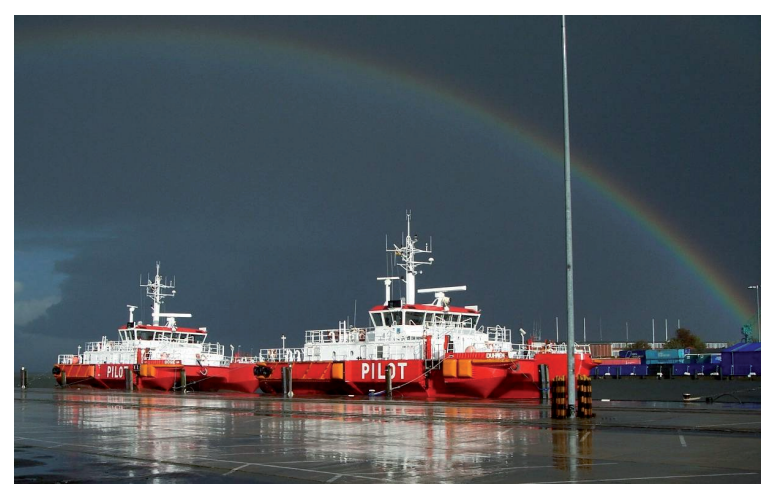

Length o.a: $25.65 \mathrm{~m}$

Displacement: $129.0 \mathrm{t}$

Breath o.a.: $14.25 \mathrm{~m}$

Speed: $18 \mathrm{kts}$

Draught: $2.70 \mathrm{~m}$

Class: GL 
In close cooperation with the Elbe Pilot Association Abeking \& Rasmussen developed technical systems tailored to the boarding procedure required, such as

- fendering system

- quick ballast system

- boarding aids

Until today each of the vessels has accumulated more than 15.000 operating hours in regular all day/all weather pilot operation.

This longtime operating since 1999 experience of SWATH vessels in a tough workboat application gives Abeking \& Rasmussen a good insight into the structural and mechanical stresses of such a vessel and as such is a valuable design feedback.

\section{0 m SWATH@A\&R® Pilot Station Ship}

Fig. 9. 50 m A\&R Pilot Station Ship.

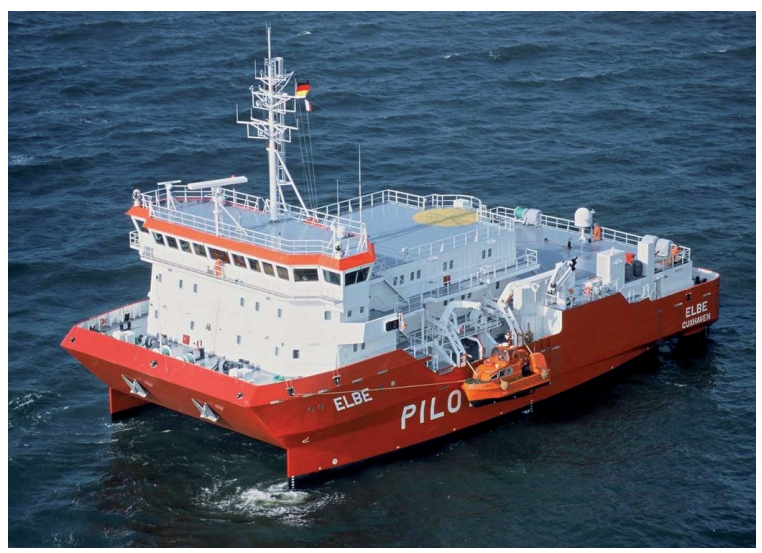

Length o.a: $49.90 \mathrm{~m}$

Displacement: $1,480.0 \mathrm{t}$

Breath o.a.: $22.55 \mathrm{~m}$

Speed: $14.2 \mathrm{kts}$

Draught: $5.90 \mathrm{~m}$

Class: GL

Since commissioning in 2000 the "ELBE" has been in continuous operation in the North Sea off Cuxhaven. She is just undergoing her second class docking and has not been in a shipyard since the class docking before.
The "ELBE" stays at sea all year round acting as a hotel ship for the off-duty Elbe Pilots. She is off station for about 12 hours when she calls Cuxhaven every 14 days for replenishment and crew change.

During approx. 40.000 operating hours which were accumulated by the "ELBE" until today a lot of operational experience in supporting the SWATH Pilot Tenders was gained. This resulted in some important improvements with regard to SWATH Pilot Tender operation and replenishment at sea.

\section{5mSWATH@A\&R®MCMV Demonstrator}

Fig. 10. A\&R MCMV Demonstrator.

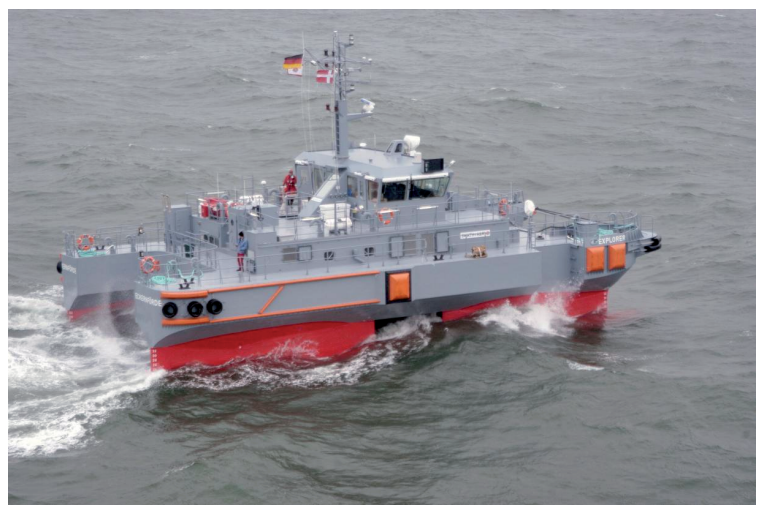

Length o.a: $26.15 \mathrm{~m}$

Displacement: $132.9 \mathrm{t}$

Breath o.a.: $14.25 \mathrm{~m}$

Speed: 16 kts

Draught: $3.20 \mathrm{~m}$

Class: GL

In 2002 the German MoD placed an order for the development of a remote operated Mine hunting System. Apart from the sonar system the sea keeping performance of the platform was a key issue. A calm and stable platform with good maneuverability is required to enhance the sonar performance. Therefore the choice was made for the SWATH@A\& $\mathrm{R}^{\oplus}$ technology. 
40m SWATH@A\&R® Motor Yacht

Fig. 11. 40 m A\&R SWATH Motor Yacht.

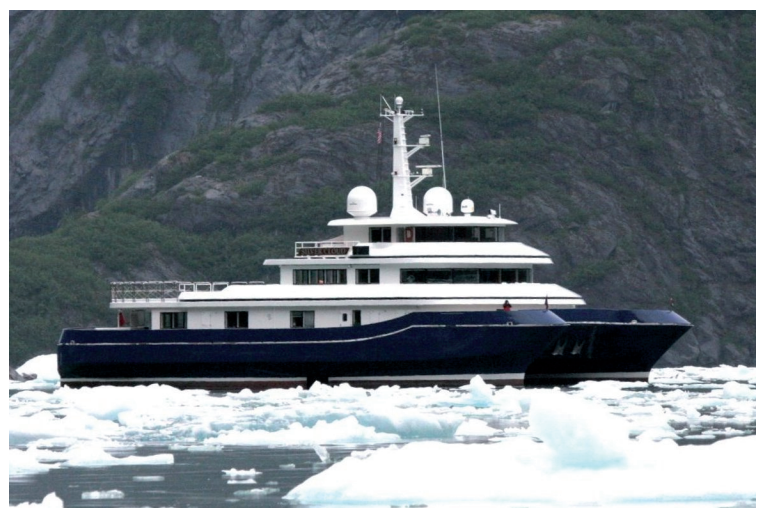

Length o.a: $40.50 \mathrm{~m}$

Displacement: $597.0 \mathrm{t}$

Breath o.a.: $17.80 \mathrm{~m}$

Speed: $14 \mathrm{kts}$

Draught: $4.10 \mathrm{~m}$

Class: GL/MCA

In 2006 Abeking \& Rasmussen secured the first order for a SWATH Motor Yacht for worldwide operation. This was the first SWATH-type Mega yacht of the world. It accommodates one yacht tender and a landing deck for a $2.5 \mathrm{t}$ helicopter.

All demanding contractual requirements for sea keeping parameter, speed and comfort were even exceeded. Her seaworthiness equals the much larger 50m SWATH@A\&R Pilot Station Ship

\section{0 m SWATH@A\&R® Pilot Station Ship}

Fig. 12. 60 m A\&R Pilot Station Ship.

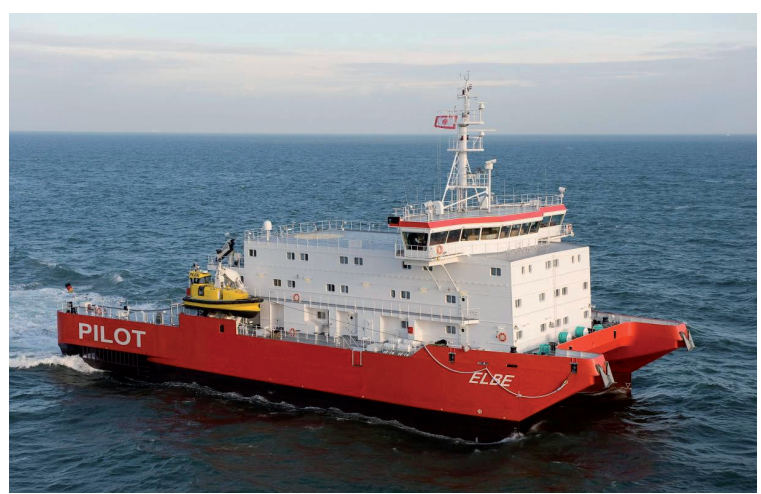

Length o.a: $60.40 \mathrm{~m}$

Displacement: $1,800.0 \mathrm{t}$

Breath o.a.: $24.60 \mathrm{~m}$

Speed: $12.5 \mathrm{kts}$

Draught: $6.0 \mathrm{~m}$

Class: GL

In 2007 the German Ministry of Transport ordered two larger variants of the existing Station Ship to serve the increasing traffic in the German North Sea to/from the ports and the Kiel Canal.

The new ships include all improvements based on the 7 years of experience with the existing ships.

\section{5 m SWATH@A\&R® Windpark Tender}

Fig. 13. A\&R Windpark Tender.

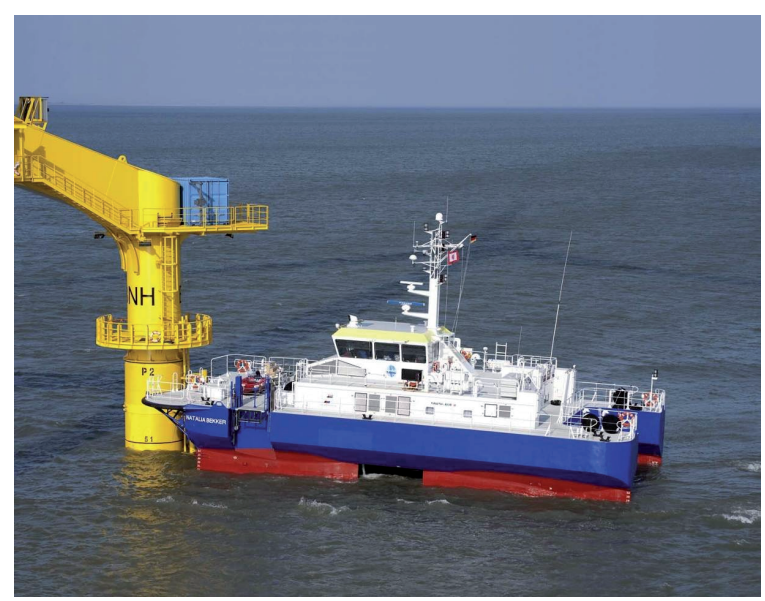

Length o.a: $26.10 \mathrm{~m}$

Displacement: $132.9 \mathrm{t}$

Breath o.a.: $13.00 \mathrm{~m}$

Speed: $18 \mathrm{kts}$

Draught: $2.70 \mathrm{~m}$

Class: GL

In March 2008 the BARD group ordered the $25 \mathrm{~m}$ SWATH@A\&R platform as service vessel for their offshore wind farm under construction in the North Sea. To achieve a high availability of the wind energy converters it is mandatory to be able to transfer service personnel to the offshore structures even in high seas. Consequently the SWATH technology was chosen. 
The 25 m SWATH@A\&R $\mathrm{R}^{\oplus}$ Windpark Tender is equipped with a special bow fender for additional damping, allowing direct boarding of the offshore structure and a dedicated diesel-electric propulsion for highest maneuverability at zero speed.

\section{5 m SWATH@A\&R® Patrol Boat}

Fig. 14. A\&R Patrol Boat.

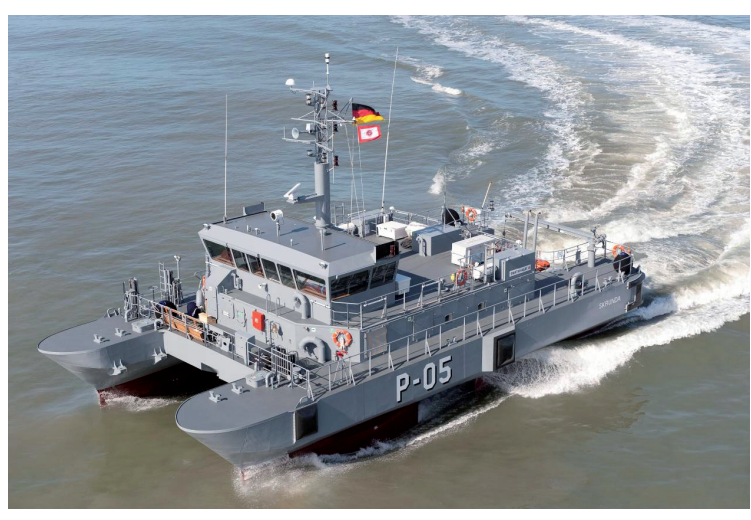

Length o.a: $25.80 \mathrm{~m}$

Displacement: $132.9 \mathrm{t}$

Breath o.a.: $14.25 \mathrm{~m}$

Speed: $20 \mathrm{kts}$

Draught: $2.70 \mathrm{~m}$

Class: GL

In 2008 the Latvian Navy placed an order for five 25m SWATH@A\& $\mathrm{R}^{\oplus}$ Patrol Boats based on the design of the $25 \mathrm{~m}$ Pilot Tender. The decision was explicitly made to benefit from the well proven seaworthiness of the compact vessels. A crew of eight can remain at sea for one week to fulfill patrol and surveillance tasks, SAR missions and to participate in international assignments.

The new vessels features a modular mission bay at the fore ship. By fitting appropriate mission modules, such as a medium caliber gun or mine hunting equipment, the capabilities of the vessels can be flexibly enhanced to suit the actually assigned task. 